To cite this article: Millie N. Horsfall (2020) Marketing of Library and Information Services in the Digital Age: Challenges, Strategies and Implications. Information Impact: Journal of Information and Knowledge Management, 11:2, 1320, DOI: dx.doi.org/10.4314/iijikm.v11i2.2

To link to this article: https://dx.doi.org/10.4314/iijikm.v11i2.2

\title{
Marketing of Library and Information Services in the Digital Age: Challenges, Strategies and Implications
}

\author{
Millie N. Horsfall \\ University of Port Harcourt, Rivers State, Nigeria
}

\begin{abstract}
This paper discussed effective marketing of library and information services in the digital age. It focused on librarians marketing themselves and library services which require the application of ICT through web 2.0 tools; these include WhatsApp, email, face book, You-tube, Twitter, LinkedIn, Telephone, etc to reach out to their clientele in order to satisfy their information needs. The study adopted a conceptual review based on previous research. It x-rays the need to market LIS to increase usage, whether onsite or remote for sustainable development. There were some challenges such as ignorance among librarians, lack of ICT infrastructure, lack of awareness of the public in their right to information, lack of fund and lack of training and retraining of library staff. However, some strategies, implications and recommendations were proffered. It was concluded that effective marketing be used to promote access to library and information services as a panacea towards sustainable Nigerian libraries in the digital age.
\end{abstract}

Keywords Marketingt, Library, Information Information services, Digital Age

CONTACT Horsfall, M. N. millie.horsfall@uniport.edu.ng University of Port-Harcourt, Rivers State, Nigeria 2020 The Author Published with License by Information Impact

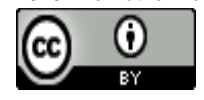




\section{Introduction}

Effective marketing of library and information service in this digital age is a process whereby Libraries and information centres put lot of effort and energy into designing information services and products and distributing them to satisfy their users. Information is being treated as the $6^{\text {th }}$ and most important resources in addition to the most traditional resources namely; man, machine, money, material and time. During the $20^{\text {th }}$ century, the key technology has been information technology, which is why it is essential to develop the appropriate information infrastructure through effectively marketing library services and ourselves as librarians and make major investments in the field of information technology (IT). The advancement of IT changed the society, thereby posing a challenge to libraries/information system professionals to meet the increasing demand of information needs of clientele (library users). One of these challenges is lack of funding, which is a perennial problem faced by libraries, such that funding is needed for some services in the library to be functional. The emergence of Electronic Information Resources (EIR) has tremendously transformed information handling and management in Nigerian academic environments and University libraries in particular. Some clienteles do not use the electronic databases, instead they prefer the print format (books. Journals, etc) There is need to market library services to increase usage, whether onsite or remote.

The purpose of this study is to find out the challenges, strategies and implication of marketing of library and information services in the digital age. The study specifically sought to:

1. examine the concept of marketing of library and information services in the digital age;

2. investigate the challenges of effective marketing of library and information service especially in the delivery of library services by library/information professionals;

3. proffer strategies to overcome these challenges and,

4. ascertain the implications for library and information professionals in handling and marketing library and information services.

\section{Literature Review}

Marketing of library and information services in the digital age, is a way of making sure libraries and librarian meet their users' needs. This will help solve most needs of the users and also enable them to visit the library if they know their needs are being met. Information has to be handled and managed effectively by librarians; thereby marketing their services by themselves to sustain the Nigerian libraries. These handling requirements are reviewed by librarians, therefore, one of the librarian's tools when it comes to library resources is Information handling and management. Information Management (IM) is the management of information in an information centre by the management information centre department. It produces information in its most useful form and at an appropriate time to various organizations, this could be done through computer operations (Nwana, 2008:98).

Computers have changed our society to an information society. Internet has changed our society from information society to a global society. Human society is undergoing a sea change due to phenomenal growth of information and application of IT in the form of high degree of computerization and transmission of electronic information. Marketing of library and information services require the applications of ICT.-Furthermore, to effectively handle and manage information, librarians need to market library and information services to their clientele. The question now is, "how can librarians effectively market library and information services in the digital age to their users so that the information needs of their users can be met?" One of the primary functions of the library is to make available to the reader the 
information materials he/she needs without waste of time. The library's basic need for survival is through information as information is a source for development in any society.

Effective information handling and management makes the library a dynamic engine for knowledge in the information age, which in turn makes the library and librarians well positioned to carry out responsibilities in order to sustain libraries and librarians in Nigerian libraries. Libraries and librarians are the pillars of knowledge because they provide very useful information on library services hence the slogan, "Librarians! Knowledge Managers! Knowledge managers! Librarians!" However, librarians are not only knowledge managers but also service providers to promote effective library and information service delivery in the digital age. This will enhance the satisfaction of users' information needs and demands.

Occasionally, digital age can be used interchangeably with computer age or information age. It is a period that is characterized by evolution in ICT (Agbo \& Anozie, 2017). Marketing concept is widely applicable in Library and Information Science (LIS) environment.. Many authors have looked at marketing of library and information services in different ways and have arrived at similar meaning. The library is a service organization and marketing of library services is crucial in information handling and management because of its dynamic nature. Marketing is a way of communicating value in an effort to extend services, which is an important aspect to libraries. It means finding what potential users need and want and tailoring library and information services to meet their demands. Dictionary of Information and Library management (2006) defined market as the number of people wishing to buy a product. While service is defined as work which supports another person's or organization's activities.

Marketing is the activity of deciding how to advertise a product; what price to charge for it etc, or the type of job in which it is done. Service as defined by Nwegbu in Ahiauzu, Akobo and Igben (2007), is the provision of work, accommodations, or ministrations desired by a customer. Information services is the assistance a librarian renders to the clientele by enabling him/her to get the information he/she wants from the library (Edom \& Edom, 2019). Marketing as defined by Singh and Shukla in Ukwoma (2014:80), is a means of ensuring that libraries, librarians and librarianship are integrated into both today's and tomorrow's emerging global culture. Marketing to them is referred to as those instruments through which information is transmitted to its members. Das and Karn in Ukwoma (2014), asserted that marketing is a belief in service, trying to achieve customer's satisfaction, an ability to assemble and interpret information for the benefit of the user. Marketing as defined by Institute of Marketing in Britain is 'the management process responsible for identifying, anticipating and satisfying customers' requirements profitably'. To Akinnawo (2018), marketing is the process by which individuals or groups obtain what they need by creating, offering and exchanging products and services with others.

Marketing involves advocating for libraries, publicizing resources and services, convincing people of the value and relevance of the library. It means not waiting passively for users but actively going out to seek them. A number of librarians around the world have gone to the streets, playgrounds, shopping centres, markets etc in search of users. Marketing can also involve envisioning the library as a business (from where the concept of marketing came) selling commodities to customers (Dike, 2009). Singh and Shukla (2009), opined that marketing is the process of planning, pricing, promoting, and distributing goods and services to create "exchanges" that satisfy the library and the customer. Marketing, according to Ibrahim (2010), is defined as any activity that is undertaken in order to provide goods and/or services that can satisfy the needs of customers. 'The library is a marketplace of ideas. However, when customers/users realize they are getting more from their libraries, they become advocates and passionate supporters for what the library do. Librarians are there to convince users to accept their help/assistance. 
"If we don't tell people how crucial libraries and librarians are, who will?". In this digital age, librarians are introduced to the concept of branding and rebranding, its processes, marketing strategies and different online platforms are open to design and market products and services to remain relevance in their role. Marketing of library and information services is absolutely a necessary agenda to a person, situation or activity for all kinds of libraries all over the world. It is a very important area for library and information science professionals. It shows that librarians are not book worms, they maintain a competitive air over other professional. They adopt social management principles, stand and face the individual with facts and figures, [making self-services]. They possess the knowledge of identifying the information needs of clients (client-oriented), and have effective communication, interviewing, and presentation skills, as well as managerial skills and good sense of humour. It must be emphasized that marketing and communication become as important as delivering the services.

As mentioned earlier, marketing of library and information services in the digital age require the application of ICT through web 2.0 tools; these include WhatsApp, email, Face book, You-tube, Twitter, LinkedIn, etc, to reach out to their clientele. Librarians need to follow the trend---be online, do not sleep, so wake up and reach out to influence things; things ICT advocacy can help librarians to do. With ICT facilities in the library, an e-newsletter can be produced. Marketing of library and information services can be achieved by libraries and librarians through; creating awareness, fliers, checkout for sponsorships, selective dissemination of information (SDI), talk shows promotions, exhibition, posters etc. Posters offer good visual communication. They can draw attention when displayed at prominent locations and provide brief information about an event, service, etc. Old and defaced posters should be replaced on a regular basis. According to Bhatt (2011), in fact, these are excellent marketing tools because they list almost all the activities of a library.

More so, Marketing library and information services can be effectively managed to advance the position of information literacy in sustaining Nigerian library services in the digital age. It helps to achieve organizational goals by determining the needs and wants of target audience, in other to make them satisfied provide information for the interest group. Libraries and librarians can create awareness through marketing of LIS by advertising [advertising is important for promoting library services. A library can advertise its products and services in newspapers, scholarly journals, magazines, newsletters, radio, television, Web, etc. Advertisements help in image-building. They can be in a short message, or staff can write longer articles on new and existing library services. Librarians can appear on local radio and TV, highlighting the new role the libraries play in the present era. There are a variety of ways of advertising online. Traditional print advertisements include brochures, pamphlets, newspaper advertisements, etc., (Bhatt, 2011)], promoting talk shows, selling ourselves and by physically distributing resources. Users can be aware of available resources in any institution through this medium; marketing of LIS, the library still has an edge over the internet. Marketing of library and information services is user- centred service; it means librarians serving the user at the point of their needs. One may ask, "What are the needs of the user?" Start by identifying the needs of the user in academic libraries, students, staff (academic and administrative staff) and find out their needs and identify with them. In public libraries; there are students, public servants and the public.

However, Gupta, (2017) pointed out that, marketing of LIS is the effective execution of all the activities involved in increasing satisfaction of users by providing maximum value to them. The services the library can provide include reference services; find out those reference materials that are very essential both online and hard copies. When libraries/librarians meet the users need, they are user friendly (a man that has friends must show himself friendly: Proverbs 18:24). Other services include loan services, 
photocopying/reprography. Effective marketing of library and information services is a way of making sure libraries and librarians market their services and themselves to meet their users' information need. Activities such as book displays, lectures, quiz, debates, seminars, competitions, exhibitions, etc., can have a positive impact on the image of the library, motivate people to come to the library and promote the use of its products and services. This will help solve the problems of the users' and their needs and also enable them to visit and use the library often.

There are some challenges associated with marketing of Library and Information Services. These include the following:

- Ignorance among librarians: some of the librarians are ignorant about the services of the library in the digital age.

- Lack of ICT infrastructure: a lot of libraries do not have up to date ICT infrastructure.

- Lack of awareness of the public on their access to information: it has been a problem for every individual to have access to the right information and at the right time and place.

- Lack of funds: for any organization to stand firm and aid development in any angle, fund is needed. In Nigeria, some libraries may not be funded to help them procure their needed materials and improve on current equipment needed by the library in this age.

- Lack of training and retraining of library staff: training and retraining of staff has posed problems in most libraries in Nigeria.

- Lack of marketing strategies: this has posed challenges to librarians/libraries who do not have the strategies to market library and information services in the digital age.

Bamigbola (2013) stated that marketing strategy is a well-structured plan that highlights the organization's goals and quest and the specific process of achieving those set of goals. Below are some strategies for marketing library and information services;

- Be a productivity expert; think of those who have connections to make things work and be creative.

- Maintain good relationships with colleagues and libraries.

- Keep daily statistics of users; it speaks for you as a librarian. Use statistics meaningfully to show the value of what has been achieved and the extent of the usage of the library facilities and infrastructure.

- Be ICT literate; apply ICT in library- know how to use web 2.0 tools like Facebook, twitter, LinkedIn, WhatsApp, e-mail, etc to reach out to users.

- Use media adverting to pass good, short and easily remembered messages and news about the library. Use stories also about real library beneficiaries to effectively communicate to users.

- Library advocacy- library and librarians/ information experts should advertise libraries; make use of advocacy for resources. Librarians can advocate through the services they provide, if librarians are not their own advocates through involvement in issues, professional organizations and our Institutions, to a great extent, no one else would.

- Library tour for new and existing members can be used to promote the library services. While on a library tour, users can be prompted to ask questions and find out more about new activities, products, and services.

- Talk about library issues with other interest groups. 
For librarians to maintain a competitive air over other professionals, they need to market themselves and library and information services in the following ways;

- As part of developing Nigerian library's access to information, librarians have to continue to learn about resources and users' needs outside their area of specialization, always learning for learning is a lifelong thing.

- Create awareness in the library environment, thereby learning how to market themselves; by knowing how to sell themselves and their skills not just to their future employer but to the constituency they are hired to serve. They need to get out of the library environment and introduce themselves to faculties, staff and students, through fliers, magazines, placing their library home page prominently on a departmental web page with their names on it especially the faculty librarians. There should be the urge to share information, any organization benefits from the free flow of information. Closed-mouthed librarians foster inefficiency, rumours and resentments. Make them aware of what you can offer them and be proactive in getting them what they need, send them alert or articles that may help them with either teaching, research, or learning needs.

- They must focus on self-promotion and review resource allocation in an increasingly competitive field. Librarians must keep basic principles of librarianship and merge them with the changing face of knowledge, information and society. Life is about change; technology has not changed what librarians do; it merely changed the way in which librarians do things.

- They must incorporate their skills and knowledge and apply them to an evolving field. If librarians want to continue to strive, they must learn to be more competitive. Librarians must understand the importance of a library's great commodity (information).

- For there to be effective marketing of library and information services, librarians need to perform better in their services, they should seek out partnerships in other areas; outsourcing of traditional functions such as cataloguing is one type of partnership that libraries have participated in.

- Libraries/librarians are to work with bookstores by sending patrons over to use newly published materials, persuading software stores to start hiring persons with MLS or even sending patrons over to the local video stores and subsidize the cost of a DVD rental.

- Librarians must reposition themselves and introduce services and systems that enable access to global and networked resources. The game changer is ICT. We as librarians have to remain relevant, market ourselves and sell ourselves.

- The librarian needs to continuously update his/her professional knowledge and skills through relevant staff training and development programmes by going to conferences, workshops, seminars, educational centres and in-house training, always learning for learning is a lifelong thing. Though the inability to have needed funding is a problem that militates against taking advantage of staff training and development programmes. Fee-based services like reprography/photocopying services should be encouraged. 


\section{Conclusion and Recommendations}

Marketing of library and information services by librarians is an attempt to influence library users on how library resources and services can be effectively managed to advance the position of information services in the digital age. For effective marketing of LIS, librarians/libraries can either learn to adapt and seek out creative solutions to change in society or find themselves going the way of the dinosaurs. Librarians should embrace change; they are to be honest with themselves about how comfortable they are with change because change is constant. Librarians should advocate for excellent library services, appropriate staffing and facilities in the context of marketing themselves and the services they provide. Advocacy uses promotion, public relations and marketing to indicate that what is currently being done within the library and its environment will be greatly enhanced by what the librarians can offer.

With increased alternatives for information, librarians must learn to gain a competitive edge and promote the added value in the services they provide. For effective information handling and management, effective marketing should be used to promote access to library and information services as a panacea towards sustainable Nigerian libraries in the digital age.

\section{References}

Agbo, A. D. \& Anozie, C. O. (2017). Exploring the strategies and challenges of public libraries in literacy development for young people in the digital age. Ebonyi Journal of Library and Information Science, 4(1), 87-95.

Ahiauzu, B., Akobo, D. I., \& Igben, M. J. (2007) Fundamentals of Library Practice. Port Harcourt, Nigeria: David stones Publishers Ltd.

Akinnawo, T. (2018). Framework and guideline for entrepreneurship development as a sustainable employment generation strategy in Nigeria. Lagos: African consulting professional LTD, p.93

Bhatt, R.K. (2011) Relevance of Ranganathan's Laws of Library Science in library marketing. Library Philosophy and Practice. Retrieved from http://unllib.unl.edu/LPP/

Dictionary of Information and Library Management (2006) $2^{\text {nd }}$ Edition. London: A \& C Publishers Ltd.

Dike, V. W. (2009) Repositioning LIS Education for Knowledge Societies. Global Review of Library and Information Science. Vol. 5 (iv).

Edom, B. O. \& Edom, E. U (2019). Marketing of information products and services in Nigerian university libraries. In Nnadozie, C. O., Uzuegbu, C. P., Nwosu, M. C., Igwe, K. N. and Akidi, J. O. Eds. University librarianship: issues and perspectives in Nigeria. Lagos: Zeh Communications, 230-242

Gupta, D. K. (2017). Marketing of library and information services: Building a new discipline for LIS education in Asia. Malaysian Journal of Library and Information Science, 8(2), 95-103. Retrieved from https://www.researchgate,net.publication

Ibrahim, A. M. (2010) Teaching Marketing and Entrepreneurship to LIS Students: The Experience of Ahmadu Bello University. Global Review of Library and Information Science. 6, 94-102 
Nwana, S. E. (2008) Information and Communication Technology (ICT): Continuity in Education Technology. Onitsha: West and Solomon Publishing Co. Ltd.

Ukwoma, S. C. (2014) Strategies for Marketing Library Services by Library and Information Science (LIS) Professionals in Nigeria. Nigerian Libraries: Journal of Nigerian Library Association. 47(1) 80. 